UDC 658.15:330.341.1

DOI https://doi.org/10.26661/hst-2019-1-78-08

\title{
CONCEPT OF FLEXIBLE MANAGEMENT AT ENTERPRISE IN DIGITALIZATION AND LEAN PRODUCTION CONDITIONS C KRISTINA ZHURAVEL
}

Engineering Institute of Zaporizhzhia National University (Zaporizhzhia, Ukraine)

E-mail: zhuravel8300@ukr.net, ORCID: 0000-0002-0114-3535

Engineering Institute of Zaporizhzhia National University, Soborny Avenue, 226, Zaporizhzhia, Ukraine, 69006

\begin{abstract}
The relevance of research on the concept of flexible management at the enterprise in terms of digitization and lean production is of considerable novelty and great practical importance, because it is implemented at the production of the Toyota plant. In addition, this study is based on the conditions of the Internet, digitalization, which introduces an analysis of new problems. The main purpose of the research is to formulate the concept of flexible management at the enterprise in terms of digitalization and lin-production and conditions for achieving its competitiveness. The following tasks have been solved: to reveal the essence of the Internet as a basis for digitalization, development of digital technologies based on computer technology, software, networks and augmented reality; to find out the essence of Agile Management 3.0, which is developing in the conditions of digitalization and lin-production; provide an analysis of self-organization in the context of Agile Management 3.0 and the impact of self-organization on the development of complex organizations, within a certain field and rules. Research Methods: Complexity theory and methodology were used to solve new problems, based on synergistic principles of self-organization, which contribute to the unification of the team, teams, management, employees and their empowerment to achieve a high level and status of the organization as a complex self-organized system. Results of the research. Agile management concept is formed, which focuses on people and teams, frequent and high quality products, close cooperation with customers and quick reaction to changes; Mechanisms of flexible management at the enterprise in terms of digitalization and rope-production are grounded and Toyota's experience is revealed. The issue of lin-production is one of the most important issues of the modern economy, its competitiveness and quality of production. The best proof of the validity of Agile management and lean ideas is the quality of Toyota cars. Practical recommendations - to develop and improve the concept of Agile management and lean-production in the conditions of digitalization.
\end{abstract}

Keywords: agile management, flexible manufacturing concept, digital production, digitalization

Formulation of the problem in general and its relation to important scientific or practical tasks.

\section{Relevance of the research topic.}

The urgency of researching the topic is that in the context of fastgrowing digitalization, new and innovative new products smartphones, tablets, social networks and applications - are beginning to take over the market. From our point of view, the best online inventions are yet to come, the Internet is still at the beginning of its development, it is just being born. Today, the intellectualization of the economy is underway, which is based on the intellectual improvement of its characteristics, the introduction of 
innovations and efficiency, which takes it to a new level. Kevin Kelly points out that "The benefits of intellectualization of inactive processes will have hundreds of times more tangible impact on our lives than the achievements of industrialization" $[8$, p.4]. The digital economy continues to grow rapidly and engage in many types of machine-based activities. And this is not fantasy or utopia. Today, the digital economy is kept on a free flow of copies, and this system of over-distribution has formed the basis of our economy. "Artificial intelligence and machines with the function of self-study are pushing the global economy to the next revolution" [8, p.19]. Today, the digital economy is linked to the industries of the future - robotics, advanced medical and biotechnology innovations, money programming, cybersecurity, and large data processing systems that affect life, changing people's lifestyles and working conditions through management and social development $1]$.

\section{Purpose and formulation of goals of the article}

The purpose of the research is to formulate the concept of flexible management at the enterprise in terms of digitalization and lean production and conditions for achieving its competitiveness.

\section{Objectives of the study:}

- to uncover the essence of the Internet as a basis for digitalization, the development of digital technologies based on computer technology, software, networks and augmented reality;
- to find out the essence of Agile Management 3.0, which is developing in the conditions of digitalization and lean-production;

- to provide an analysis of selforganization in the context of Agile Management 3.0 and the impact of self-organization on the development of complex organizations, within a certain field and rules;

- to formulate the concept of Agile-management, which focuses on people and teams, frequent and highquality products, close cooperation with customers and rapid reaction to changes;

- to justify the mechanisms of flexible management at the enterprise in terms of digitalization and leanproduction and to reveal the experience of Toyota.

Research Methods: Complexity theory and methodology were used to solve new problems, based on synergistic principles of selforganization, which contribute to the unification of the team, teams, management, employees and their empowerment to achieve a high level and status of the organization as a complex self-organized system.

An analysis of the latest research and publications that started this issue and which the author relies on

In our research, we draw on the works of Appelo Y. Management 3.0. Agile Management. Leadership and Team Management. " (Kharkiv, 2019, 432 pp.) [2]; Brinolfsson E., McAfee E. The Second Age of Machines: Work, Progress, and Prosperity in the Times of Emergency Technologies. (Kyiv, 2016, p. 236) [3]; James P. 
Womack, Daniel T. Jones, Daniel Roos. The machine that changed the world. History of the lean-production - Toyota's secret weapons in the automobile wars (Kyiv, 2017, 288 p.) [6]; Kelly Kevin. Inevitable. 12 technologies that shape our future (Kyiv, 2018, p. 304) [8]; Ernst Ulrich von Weizseker, Anders Wyckman. Come On!

Capitalism, shortsightedness, population and the destruction of the planet. Report to the Roman Club (Kyiv, 2019, 376 p.) [7]; Ross Alec. Industries of the Future (Kyiv, 2017, 320 p.) [10]. M.Azhazh's works were used for the analysis of problems of the digital society, management and man [1]; V. Voronkova [4, 5]; R. Oleksenko [9]; A. Skull [11]; O. Cherep [11] and others.

Selection of previously unresolved parts of the general problem addressed by the article

In the future, the situation may be such that the first true artificial intelligence is born not in a single supercomputer, but in a superorganism consisting of a billion computer chips, called a network. It will have a planetary scale, but it will be slim, built-in and easily attached. The advent of artificial intelligence accelerates other shifts, the network itself contributes to the intellectualization of itself and becomes more and more supernatural [1]. The real revolution will come when everyone has at their fingertips personal robots, and jobs and machines will do the basic work. At the same time, there is a sharp breakthrough in the biological sciences, enabling people to live longer and be healthier. In any part of the world, people can receive, use, code, save, spend, or send money. All these innovations can create opportunities for humanity, but they increase the risk that malicious users will be able to cause systematic damage to the international economy.

Outline of the main research material with justification of scientific results.

\section{Rationale for the study}

1. The Internet as the basis of digitalization

The Internet has become an ocean of scattered, at first glance, information, and nowadays there is an opportunity to connect and benefit from it. "If in the agrarian era the main raw material was land, in the industrial - iron, then in the information age raw materials are data" [2, p. 20]. The economy needs transformation today. Improving resource efficiency is only a step in the right direction, no less important is the movement towards an economy based on renewable materials, in the circulation of material flows and taxes used to balance demand [11, p.256263]. In the absence of all this, the benefits of efficiency gains are quickly dampened by the combination of the effects of returns on economic growth. "Today we need a new business logic. Circulating business models need to be replaced by linear ones. One of the major challenges for the future is to create a breakthrough in the concept of services instead of products for a wide range of consumer goods - computers, mobile phones, home appliances, cars, furniture and 
real estate. The same principles can be applied even in the real estate market [7, p. 171]. The transition to a new business logic requires decisive action in the formulation of management policy and culture. The cost structure in the economy has serious disadvantages: financial capital is overestimated, while social and natural capital is undervalued. Given these shortcomings, the circulating economy is unable to manifest itself.

\section{Developing digital} technologies based on computer hardware, software and networks

Today, we are working at an amazing time in digital technology based on computer hardware, software and networks that have reached some capacity. And these changes brought about by the digital technology and digital economy are of immense benefit. Digitization is improving the material world and contributing to the development of a digital economy that creates new jobs and jobs. Economics historians are in favor of the opinion expressed by Martin Weitzman: "The long-term growth of the digital economy depends on the dynamics of technological progress [3, p.15]. Rapid and accelerated digitization can lead to economic destabilization as computers become more powerful and companies need to be reduced, so technological advancements can leave some people out of work as they continue to evolve. The problems of the digital revolution can be overcome, but first we must understand them [10, p.256-263]. With technology, the economy is able to produce more products every year, with the same resources, including labor, as all of this work is influenced by digital technology, which means that every hour of work gets more value than before. The net effect is to reduce the demand for less skilled labor, which is today called qualification-asymmetric technical changes [3, p. 108].

\section{Augmented reality}

Augmented reality requires skilled workers. The companies with the highest IT investments tend to make the biggest organizational changes related to growing demand for skilled work, which requires more creativity from entrepreneurs, managers and employees, and promotes computer rankings and computer well-being. Algorithms are the supervisors of the next generation of digital economy. But for this purpose it is necessary to develop digital economy, digital management and digital marketing, which change the world and create ecosystem of new services, jobs, business models and industry [5, p.2021]. Successful innovators ask users to embrace new values, skills, behaviors, terminology, ideas, expectations, aspirations, and embrace new trends.

Agile Management 3.0 in terms of digitalization and lean-production

Agile 3.0 management is called flexible in terms of digitalization and lean production, as it helps to manage the enterprise as a sophisticated adaptive system that requires flexible management, smart and practical management, capable of solving problems in the face of stochastic information and instability. For flexible management, a synergistic methodology can be used, in the 
context of which complexity methodology, dynamic systems methodology, chaos analysis, uncertainty and instability are developed. Management 3.0 is based on the theory of complex systems, which is part of the science of managing people and their relationships in the organization [1, p.15]. Management 3.0 examines the enterprise from six perspectives, based on the mechanisms of flexibility and complexity. Flexible Management 3.0 is formed in such a way that it is necessary to: 1) form a structure; 2) develop competencies; 3) set limits; 4) empower teams; 5) add energy to people; 6) to improve everything at the enterprise or organization in the conditions of development of information society in the era of globalization, as R.I. Oleksenko notes [9, p.29-232]. The theory of complex systems indicates that the use of linear thinking to solve complex problems is fraught with painful errors. For complex systems, a more holistic approach is needed that offers a holistic view of the interactions that occur within groups of people. Activating people becomes the first imperative of the 3.0 management model, as only people are the element capable of managing organizations as complex systems, in which emergent behavior prevails, which should be brought to integrity.

4. Self-organization in the context of management 3.0

Self-organization in the context of management 3.0 is extremely necessary in connection with its transformation into integrity. As an example, the self-organization of atoms allowed matter to rise to the next level - the level of molecules. This fact has resulted in millions of species of molecules that have accumulated into other objects. Biological cells have organized themselves into millions of different species, resulting in consciousness. Subsequently, self-organization helped this new system reach an even higher level. Tribes, societies, cities, businesses, and governments emerged. Since the creation of the Universe, everything that has arisen in it has been formed through selforganization. "Self-organization is the process of emergence in a system of structures or forms that is not the result of centralized or external influence or planning" [2, p. 128]. As Jürgen Appello testifies, "selforganization is a natural norm" $[2, \mathrm{p}$. 128]. This is the behavior of typical dynamic systems, whether built into such systems by atoms, molecules, viruses, species, or companies, even software developers. Any system, according to the theory of complexity, self-organizes, can have its own direction of development, possible

\section{Impact of self-organization on} the development of complex organizations

Organizations should be orderly, chaotic and complex. Organized organizations are not unique to creativity and they lack innovation. All activities are subject to bureaucratic rules and the organization's behavior is characterized by regularity and predictability, which is called ineffective. There can be a lot of creativity in chaotic organizations, but 
creativity is not structured or predictable, no subordination in the organization arises, everyone acts as they please. Complex organizations are located somewhere in the middle, in complex organizations employees rarely give themselves powers, and their powers are vested in managers, who are faced with a balance between a directive style of management and delegation. This is one of the classifications and approaches to the search for flexible management mechanisms. The question is how to set the rules of the organization so that it does not become too orderly or too chaotic, and move in the direction of chaos. Managers cannot be held responsible for self-organization as well, since it ceases to be selforganization. According to the rules of flexible management, each organization is a complex adaptive system, the functions of which are delegated to its members. Selforganization is able to independently respond to the chaos when its parameters are in a certain critical interval, and the task of managers to adjust the parameters that will contribute to the development of a self-organizing system, which will not hurt the creativity, innovation and adaptability of the system [2, p.181].

However, one self-organization is not enough as it is necessary to direct the organization to value creation. At least managerial efforts are needed to direct the self-organization process towards value creation for all stakeholders. It is a matter of "setting limits" rather than directly affecting people's behavior, since only the system of constraints can be controlled. Managers must create the basic conditions in the organization that make the organization a good and safe employer, as well as protect people and resources, ensuring the integrity of the organization and taking care of it and employees [2, p.64].

6. Self-organization of organizations within the field and rules

The organization is self-organizing within the field and rules set by the associations, however, the manager must ensure that the result of the chosen basic rules is successful for all stakeholders. There are many opportunities for an organization to become successful and effective, creating boundaries, constraints, all of which are called managed evolution. There is a difference between managers and leaders: if leaders set directions, then managers only support movement in the chosen direction. People follow the leader of good will, and this phenomenon is called adaptive or emergent leadership, the leadership that emerges during the adaptation of the social system. In a complex system, a single leader is not needed; in fact, cross functional teams can work better when there are multiple leaders, and everyone in their specialization. Becoming a leader is not the overriding goal of a manager, it is his duty to determine the proportion between leadership and board, since the task of the manager is to cultivate emergent leadership, which follows the rules laid down in administrative leadership. The role of management is 
to manage the systems, not the people who form these systems [2, p.4].

7. The concept of Agile management as a response to the power of bureaucracy, focused on people and teams, frequent and high quality products, close collaboration with customers and rapid response to change

So Agile's approach to software development, which emerged as a reaction to the bureaucracy's power, as well as to private methods, because the Agile approaches outlined in the Agile Manifesto focus on people and teams, frequent and high quality products, is tight customer collaboration and rapid response to changes with a minimum of preplanning. The values and principles of flexible approaches are implemented through various methods such as Scrum and Extreme Programming. Seven dimensions (people, functionality, quality, tools, time, value, process) should be looked at in your organization. The use of ideas of complexity theory has considerable prospects for management as a discipline in the practical management of organizations. The theory of complex systems favors a multidisciplinary approach to problem solving, it assumes the existence of common laws in the behavior of systems studied by different scientific disciplines and advances the approach to solving problems based on the concepts of different sciences, including municipal management, as it is noted by V. Voronkova [4].

8. Mechanisms of flexible management at the enterprise in the conditions of digitalization and leann-production

We are following the mechanisms of flexible management at the enterprise in terms of digitization and lean production, exemplified by Toyota's success in the automotive industry, based on the principles and methods of rope production that they have introduced over the two decades since World War II. Now these methods are seeping into every corner of the planet. Toyota employees have shaved off the flexibility of their work responsibilities and actively promoting the company's interests by initiating improvements rather than simply responding to problems [6]. In the long run, the labor force has made constant costs, because old equipment can be written off as scrap metal, and human resources will have to be squeezed out for a maximum of forty years of labor. Accordingly, it was advantageous for the company to constantly improve the skills of its employees in order to maximize not only their physical strength but also their knowledge of experience [6]. At the Toyota plant, workers were able to stop the line immediately if they found a problem and after stopping the pipeline, the entire team worked to eliminate the error. Workers were taught to systematically track every mistake down to the root cause (and to do so, ask the question "why?" At each level where the problem was found), and then come up with a solution so that the error would never happen again [10].

\section{Toyota experience}

The more experience teams have gained in identifying and tracking 
problems down to the root causes, the less they stop the container tape. At modern Toyota plants, where each worker had the right to stop the line, productivity reached $100 \%$, which is a sign of good plant management. The best proof of the agile management and lean production ideas is the quality of Toyota cars. Each supplier had to produce parts qualitatively to meet the demand of the next stage of production and to be sensitive to changes in market demand. Product development is inevitably linked to both process organization and production technology [6, p.88]. Thus, Toyota's new production system was particularly well suited to benefit from the ever-changing changes in consumer requirements for cars and vehicle technology in general. Thanks to the lean methods and lean principles, the design, product quality and speed of response to changes in the consumer environment have improved dramatically. The world of lean-production, lean-methods and lean-technologies has prevailed in the world. Toyota Economy Manufacturing Principles Completed Forming before the 1960s. The issue of lean production is one of the most important issues in today's economy, its competitiveness and quality of production.

\section{Conclusion}

Digital progress is creating new wonders that are becoming a part of life today, just like the wonders of past centuries - planes, skyscrapers, elevators, cars, refrigerators and washing machines. The future is in digital economy and digital progress. Public authorities will work more efficiently if they apply the principles of the digital industries and use digital services to drive digital innovation in the economy

It is recognized that for many organizations, the relationships between the elements of the system are dynamic rather than static. For many organizations, innovation is the key to survival, driven by five drivers: knowledge, creativity, motivation, personality, diversity. Successful teams need knowledge, original and useful results that cannot be obtained without creativity; employees achieve outstanding results through motivation; diversity increases the resilience and flexibility of the organization; personalities must possess basic qualities that enable them to be more productive. The existence of the organization as a single whole organism requires the presence of all of the following conditions. Scientists have identified and explored such phenomena as autopoiesis (self-construction or ways, systems construct themselves), identity (how systems can be recognized), homeostasis (the ability of systems to maintain stability), and adaptability (how systems interact with the environment).

\section{REFERENCES}

1. Azhazha M.A.(2008). Derzhavne regulyuvannya investicij v lyudskij kapital yak faktor intelektualnogo rozvitku suspilstva. Avtoreferat dis. stupenya kand. nauk z derzh. upravlinnya: spec. 25.00. 02 «Mehanizmi derzhavnogo upravlinnya.

2. Appelo Yurgen (2019). Menedzhment 3.0. Agile-menedzhment. Liderstvo ta upravlinnya komandami». Harkiv: Vid-vo «Ranok: Fabula». 432 s.

Concept of flexible management at enterprise in digitalization and lean production conditions 
3. Brinolfsson E., Makafi E. (2016). Druga epoha mashin: robota, progres ta procvitannya v chasi nadzvichajnih tehnologij. Kiyiv : FUND.236 s.

4. Voronkova V.G. (2004). Municipalnij menedzhment Kiyiv: Profesional. S.64.

5. Voronkova V.G. (Cifrova ekonomika \& cifrovij menedzhment informacijnogo suspilstva // Zbirnik materialiv XIII Mizhnarodnoyi naukovo-praktichnoyi konferenciyi «Upravlinnya socialnoekonomichnim rozvitkom regioniv ta derzhavi» / [za red. A.V. Cherep]. Zaporizhzhya : Vidavnictvo ZNU, 2019. S. 20-21.

6. Dzhejms P. Vomak, Deniel T.Dzhons, Deniel Rus (2017). Mashina, sho zminila svit. Istoriya lin-virobnictva -tayemnoyi zbroyi «Tojoti»v avtomobilnih vijnah. Kiyiv: Pabulum, 2017. 388 s.

7. Come On! Kapitalizm, nedalekoglyadnist, naselennya i rujnuvannya planeti. Dopovid Rimskomu klubu / Ernst Ulrih fon Vajczeker, Anders Vijkman; pereklad z angl.Yu.Sirosh; za nauk. red. V.Vovka, V.Butka. K.: Samit-Kniga, 2019. 276 s.

8. Kelli Kevin. Nevidvortne. 12 tehnologij, sho formuyut nashe majbutnye. / per. z angl. Nataliya Valevska. K: Nash format, 2018. 304 s.

9. Oleksenko R.I. Filosofiya rozvitku informacijnogo suspilstva v epohu globalizaciyi / Gileya. 2015. Vip.38. S. 229-232.

10. Ross Alek. Industriyi majbutnogo / Per. z anl. Nataliya Koshmanenko. K.: Nash format. 2017. $320 \mathrm{~s}$.

11. Cherep A.V. and O. H. and Cherep O.H. and Krylov D.V. and Voronkova V. H. Methodological approach to the redistribution of investment projects within a company According to formal criteria // Financial and credit activity-problems of theory and practice. Volume 28, Issue 1. 2019. r. 256-263.

Журавель Крістіна Олександрівна - аспірантка кафедри менеджменту організацій та управління проектами, Інженерний інститут Запорізького національного університету (Запоріжжя, Україна)

E-mail: zhuravel8300@ukr.net, ORCID: 0000-0002-0114-3535

\section{КОНЦЕПЦІЯ ГНУЧКОГО МЕНЕДЖМЕНТУ НА ПІДПРИЕМСТВІ В УМОВАХ ЦИФРОВІЗАЦІї ТА ЛІН- ВИРОБНИЦТВА}

Анотація. Актуальність дослідження концепції гнучкого менеджменту на підприємстві в умовах цифровізації та лін-виробництва маю значну новизну та велике практичне значення, тому що вона упроваджується на виробництві заводу «Тойота». Крім того, дане дослідження базується на умовах Інтернет, цифровізації, що вносить аналіз нових проблем. Головна мета дослідження - сформувати концепцію гнучкого менеджменту на підприємстві в умовах цифровізації та лін-виробництва та умови досягнення його конкурентоспроможності. Поставлено вирішити наступні завдання: розкрити сутність Інтернет як основи цифровізації, розвитку цифрових технологій на основі комп'ютерної техніки, програмного забезпечення, мереж та доповненої реальності; з'ясувати сутність Agile-менеджмент 3.0, що розвивається в умовах цифровізації та лін-виробництва; дати аналіз самоорганізації в контексті Agileменеджменту 3.0 та вплив самоорганізації на розвиток складних організацій, у межах певного роду поля і правил. Методи дослідження: для вирішення нових проблем було використано теорію та методологію складності, в основі якої синергетичні принципи самоорганізації, що сприяють об’єднанню колективу, команд, керівництва, співробітників та їх наділення на досягнення високого рівня і статусу організації як складної самоорганізованої системи. Результати дослідження. Сформовано концепцію Agile-менеджменту, що фокусується на людях і командах, частих і високоякісних продуктах, тісній співпраці з замовниками й швидкій реакції на зміни; обгрунтовано механізми гнучкого менеджменту на підприємстві в умовах цифровізації та лінвиробництва та розкрито досвід «Тойоти». Питання лін-виробництва - це одне 3 найважливіших питань сучасної економіки, тї конкурентоспроможності та якості

(C) Kristina Zhuravel, 2019 
виробництва. Найкращим підтвердженням правильності ідей Agile-менеджменту та лінвиробництва є якість автомобілів «Тойота». Практичні рекомендації - розвивати та удосконалювати концепцію Agile-менеджменту та лін-виробництва в умовах цифровізації.

Ключові слова: концепція гнучкого менеджменту, лін-виробництво, цифровізація, Agile-менеджмент

Журавель Кристина Александровна - аспирантка кафедры менеджмента организаций и управления проектами, Запорожский $\quad$ национальный $\quad$ университет Инженерный институт (Запорожье, Украина)

E-mail: zhuravel8300@ukr.net

ORCID: 0000-0002-0114-3535

\section{КОНЦЕПЦИЯ ГИБКОГО МЕНЕДЖМЕНТА НА ПРЕДПРИЯТИИ В УСЛОВИЯХ ЦИФРОВИЗАЦИИ И ЛИН-ПРОИЗВОДСТВА}

Аннотация. Актуальность исследования концепции гибкого менеджмента на предприятии в условиях цифровизации и лин-производства имеет значительную новизну и большое практическое значение, потому что она внедряется на производстве завода «Тайота». Кроме того, данное исследование базируется на условиях Интернет, цифровизации, которая вносит анализ новых проблем. Главная цель исследования сформировать концепцию гибкого менеджмента на предприятии в условиях цифровизации и лин-производства и условия достижения его конкурентоспособности. Поставлено решить следующие задачи: раскрыть сущность Интернет как основы цифровизации, развития цифровых технологий на основе компьютерной техники, программного обеспечения, сетей и дополненной реальности; определить сущность Agile-менеджмента 3.0, который развивается в условиях цифровизации и линпроизводства; дать анализ самоорганизации в контексте Agile-менеджмента 3.0 и влияние самоорганизации на развитие сложных организаций, в пределах определенного рода поля и правил. Методы исследования: для решения новых проблем использована теория и методология сложности, в основе которой синергетические принципы самоорганизации, которые способствуют объединению коллектива, команд, руководства, сотрудников и их наделение полномочиями, расчитанными на достижение высокого уровня и статуса организации. Результаты исследования: сформирована концепция Agile-менеджмента, которая фокусируется на людях и командах, высококачественных продуктах, тесном сотрудничестве с клиентами и быстрой реакции на изменения; обоснованы механизмы гибкого менеджмента на предприятии в условиях цифровизации и лин-производства и раскрыт опыт «Тайоты». Вопросы линпроизводства - это один из самых важных вопросов современной экономики, ее конкурентоспособности и качества производства. Самым лучшим подтверждением правильности идей Agile-менеджмента и лин-производства есть качество автомобилей «Тайота». Практические рекомендации - развивать и усовершенствовать концепцию Agile-менеджмента и лин-производства в условиях цифровизации.

Ключевые слов: концепция гибкого менеджмента, лин-производство, цифровизация, Agile-менеджмент.

Received date 10.09.2019

Accepted date 12.10.2019

Published date 12.11.2019

Concept of flexible management at enterprise in digitalization and lean production conditions 